\title{
The NADH-dependent glutamate dehydrogenase enzyme of Bacteroides fragilis Bf1 is induced by peptides in the growth medium
}

\author{
Garth L. Abrahams and Valerie R. Abratt \\ Author for correspondence: Garth L. Abrahams. Tel: +27 21 6503258. Fax: +27216897573. \\ e-mail:val@molbiol.uct.ac.za
}

Microbiology Department, University of Cape Town, Private Bag, Rondebosch 7701, South Africa

\begin{abstract}
Bacteroides fragilis Bf1 possesses two enzymes having glutamate dehydrogenase (GDH) activity. One is dual cofactor NAD(P)H-dependent, while the other has NADH-specific activity. The gene encoding the NADH-GDH (gdhB) was cloned by complementation of the glutamate auxotrophic mutant Escherichia coli MX3004 and the recombinant protein was characterized with respect to the GDH activities present in the parental organism grown under different nitrogen conditions. The NAD(P)H-dependent GDH of $B$. fragilis was confirmed to be most active under high ammonia conditions, but the NADHspecific GDH levels were increased by high peptide concentrations in the growth medium and not regulated by the levels of ammonia. Northern blotting analysis showed that gdhB regulation was at the transcription level, with a single transcript of $\sim 1.6 \mathrm{~kb}$ being produced. GDH activity was demonstrated by zymography of the parental and recombinant enzymes. The recombinant GDH was NADH-specific and co-migrated with the equivalent enzyme band from $B$. fragilis cell extracts. The gdhB structural gene comprises $1335 \mathrm{bp}$ and encodes a protein of $445 \mathrm{aa}(49 \mathrm{kDa})$. Comparisons of the derived protein sequence with that of GDH from other bacteria indicated that significant sequence homology and conservation of functional domains exists with enzymes of Family l-type hexameric GDH proteins.
\end{abstract}

Keywords: Bacteroides fragilis, nitrogen metabolism, glutamate dehydrogenase

\section{INTRODUCTION}

Bacteroides fragilis is an important anaerobic opportunistic pathogen of humans. It occurs normally in the digestive tract, but can cause severe abscess formation and sepsis when outside this environment. One of the factors thought to be involved in the pathogenicity of this bacterium is the production of proteases, which are, in turn, regulated by the levels of nitrogen available (Gibson \& MacFarlane, 1988a, b).

In prokaryotes, glutamate dehydrogenase (GDH) and the dual enzyme system, glutamine synthetase (GS) and

Abbreviations: $\mathrm{CFE}$, cell-free extract; GDH, glutamate dehydrogenase; GOGAT, glutamate synthase; GS, glutamine synthetase.

The GenBank accession number for the sequence reported in this paper is U78108. glutamate synthase (GOGAT), are the most important routes by which ammonia may be assimilated (Reitzer \& Magasanik, 1987). GDH is an extremely important enzyme which links carbohydrate and nitrogen metabolism (Smith et al., 1975) and the physiological roles of GDHs as anabolic and/or catabolic enzymes are generally defined by the nature of their cofactor specificity (Joe et al., 1994). NADP(H)-specific GDH enzymes usually catalyse the assimilation of ammonia by reductive amination of $\alpha$-ketoglutarate to form L-glutamate (anabolic), while $\mathrm{NAD}(\mathrm{H})$-dependent $\mathrm{GDH}$ enzymes catalyse the reverse reaction (catabolic).

Yamamoto et al. (1984) have suggested that GDH activity may play the primary role in nitrogen assimilation in B. fragilis, since the levels of GDH were very much higher than GS and cells which had their GS activity inhibited with methiosulfoxamine did not show a decrease in cell growth rate. 
Nitrogen metabolism in $B$. fragilis has been shown to have several unusual features when compared to the Enterobacteriaceae. Ammonia is not replaced by amino acids as the source of nitrogen for growth (Varel \& Bryant, 1974), while peptides can also be utilized. The enzymes involved in the assimilation of nitrogen are a structurally novel form of GS (GSIII) (Southern et al., 1986, 1987; Hill et al., 1989), two GDHs (Yamamoto et al., 1984, 1987a, b; Saito et al., 1988) and GOGAT. These enzymes have been shown to be regulated by the levels of ammonia available. GS is induced under low ammonia conditions and is regulated at the level of transcription (Southern et al., 1986, 1987; Abratt et al., 1993).

The two GDH enzymes were first identified by Yamamoto et al. (1984) who concluded that one had dual specificity for pyridine nucleotides $[\mathrm{NAD}(\mathrm{P}) \mathrm{H}]$, while the other was NADH-specific. Characterization of the activities of these enzymes showed that the $\mathrm{NAD}(\mathrm{P}) \mathrm{H}$-dependent GDH was induced by low concentrations of ammonia, whereas high ammonia concentrations were thought to partially induce the NADHdependent GDH. Further characterization of the former enzyme at the protein level showed that the activity was controlled through a reversible activation/inactivation mechanism which was regulated by ammonia (Yamamoto et al., 1987a, b; Saito et al., 1988).

The presence of two GDH enzymes [a dual NAD(P)Hand an NADH-dependent enzyme] has recently been reported in another colonic Bacteroides species, $B$. thetaiotaomicron (Baggio \& Morrison, 1996). Although both enzyme activities were detectable under all growth conditions tested, the highest specific activities were observed at limiting ammonia concentrations. The gdhA gene has been cloned from this organism and shown to encode the $\mathrm{NAD}(\mathrm{P}) \mathrm{H}$-utilizing GDH enzyme. This gene required downstream DNA sequences (or the sequence supplied in trans) for activity, but not transcription, in Escherichia coli. Insertional inactivation of the gene in B. thetaiotaomicron did not generate a glutamate auxotrophic mutant, indicating the presence of a second enzymic pathway catalysing ammonia assimilation and glutamate biosynthesis. The NADH-dependent GDH enzyme from this organism has also been cloned $(g d h B)$ and has been shown to be most active in a medium containing peptides (Mark Morrison, personal communication).

The anaerobic rumen bacteria Ruminococcus flavefasciens and Prevotella spp. have been shown to possess NAD(P)H-dependent GDH activity, induced under ammonia limitation conditions (Duncan et al., 1992; Wen \& Morrison, 1996, 1997). In Prevotella spp. it is repressed by the presence of peptides. Prevotella brevis, however, has an additional NADH-dependent GDH enzyme, which is induced by growth in peptides as sole nitrogen source.

Neither of the GDH enzymes of $B$. fragilis has been cloned or characterized at the molecular level, nor have the mechanisms underlying the control of GDH activity and the distinctive roles of the two enzymes in nitrogen assimilation in this organism been elucidated. In this work we report the cloning and molecular characterization of the NADH-specific GDH and its response to nitrogen sources as compared to the $\mathrm{NAD}(\mathrm{P}) \mathrm{H}$ dependent GDH enzyme in B. fragilis.

\section{METHODS}

Bacterial strains, plasmids and growth conditions. $B$. fragilis Bf1 (Mossie et al., 1979), isolated from human faeces, was used to study GDH production and for the preparation of a gene library using plasmid pEcoR251 (Zabeau \& Stanley, 1982). Plasmid pMT104 (Wehnert et al., 1990) was used as a negative control for cloned GDH activity. B. fragilis Bf1 was grown routinely at $37^{\circ} \mathrm{C}$ in brain heart infusion (BHI) broth (Difco) and agar (1.5\%), supplemented according to Abratt $e t$ al. (1985), in a Forma Scientific anaerobic chamber (atmosphere $85 \% \mathrm{~N}_{2}, 10 \% \mathrm{H}_{2}$ and $5 \% \mathrm{CO}_{2}$ ). E. coli strains were grown aerobically at $37^{\circ} \mathrm{C}$ in YT broth (Sambrook et al., $1989)$ and agar $(1.5 \%)$. For anaerobic growth, sodium nitrate $(0.2 \%)$ and glucose $(0.5 \%)$ were added to the YT broth and the cells grown in the anaerobic chamber. Screening for $g d h$ genes was carried out in E. coli MX3004 (Castano et al., 1992) on glucose minimal medium (GMM; Sambrook et al., 1989) containing $13 \mathrm{mM} \mathrm{NH}_{4} \mathrm{Cl}$ as sole nitrogen source (GMMN). Ampicillin (Ap) and chloramphenicol (Cm) were used at final concentrations of 100 and $50 \mu \mathrm{g} \mathrm{ml}^{-1}$, respectively, in the medium when required.

Nitrogen regulation studies in $B$. fragilis were conducted in GMM broth (Varel \& Bryant, 1974), modified as described by Abratt et al. (1993). The medium was supplemented with 0.5 , 5.0 or $50 \mathrm{mM} \mathrm{NH}_{4} \mathrm{Cl}$ (low, medium and high ammonia, respectively), or 0.25 or $1.25 \%$ tryptone (low and high peptides, respectively).

General recombinant DNA procedures. All DNA manipulations were performed according to standard procedures (Sambrook et al., 1989). Chromosomal DNA preparations from B. fragilis were prepared by the method of Wehnert $e t$ al. (1990) and E. coli JM109 chromosomal DNA, prepared according to Sambrook et al. (1989), was used as a control in Southern hybridization analysis. Plasmid DNA preparations were isolated by the alkaline lysis method of Ish-Horowitz \& Burke (1981) or with the Nucleobond AX DNA isolation kit (Macherey-Nagel). Plasmid DNA was introduced into E. coli by the transformation of competent cells (Sambrook et al., 1989) with strain MX3004 as the recipient for GDH selection and strain JM109 (Yanisch-Perron et al., 1985) for routine DNA cloning and manipulation procedures. All endonuclease restriction enzymes were purchased from Amersham or Boehringer Mannheim and were used as specified by the manufacturer. Electrophoresis was performed on $0.8-1.5 \%$ agarose gels according to standard procedures. DNA fragments were purified from agarose gels with the Geneclean kit (Bio101).

Construction and screening of the recombinant DNA library. The construction of the $B$. fragilis genomic library has been described by Southern et al. (1986). Recombinant plasmids were transformed into competent E. coli MX3004 cells. Colonies were screened for expression of GDH or GOGAT activity by plating transformed cells onto GMMN medium containing $\mathrm{Ap}$ and $\mathrm{Cm}$ and screening for glutamate prototrophy after $2 \mathrm{~d}$ incubation.

Preparation of cell-free extracts (CFEs). Cultures were grown to early stationary phase and $100 \mathrm{ml}$ was harvested by 
centrifugation $\left(10000 \mathrm{~g}\right.$ for $10 \mathrm{~min}$ at $\left.10^{\circ} \mathrm{C}\right)$. The cells were washed three times with $50 \mathrm{mM}$ Tris $/ \mathrm{HCl}(\mathrm{pH} \mathrm{8.0)}$ and resuspended in $5 \mathrm{ml}$ of the same buffer. Cells were disrupted by sonication $\left(4^{\circ} \mathrm{C}\right)$ at $95 \mathrm{~W}$ using five $30 \mathrm{~s}$ bursts with $30 \mathrm{~s}$ cooling intervals (VirSonic Digital 475 Cell Disruptor), centrifuged at $15000 \mathrm{~g}$ for $15 \mathrm{~min}$ at $4{ }^{\circ} \mathrm{C}$ and the CFE used for GDH assays. For experiments to measure the activity of the enzyme under anaerobic conditions, cells were harvested under anaerobic conditions, washed with anaerobic $50 \mathrm{mM}$ Tris/ $\mathrm{HCl}(\mathrm{pH} \mathrm{8.0)}$ buffer and disrupted using a French pressure cell (220800 kPa; SIM, Aminco). The disrupted cell material was collected in a nitrogen-filled tube which was then centrifuged and the CFE removed under anaerobic conditions. Assays were conducted under strict anaerobic conditions in the anaerobic chamber.

GDH enzyme assays. GDH activity was assayed spectrophotometrically (DU650 spectrophotometer, Beckman) by following the decrease in $A_{340}$ during oxidation of NADPH or NADH (Yamamoto et al., 1984). The reactions were conducted at $25^{\circ} \mathrm{C}$ in $1.0 \mathrm{ml}$ reaction mix containing $100 \mathrm{mM}$ Tris $/ \mathrm{HCl}(\mathrm{pH} 8 \cdot 0), 40 \mathrm{mM} \mathrm{NH}_{4} \mathrm{Cl}, 5 \mathrm{mM} \alpha$-ketoglutarate and $0.15 \mathrm{mM}$ NADPH and were initiated by the addition of $50 \mu \mathrm{l}$ CFE $(75 \mu \mathrm{g}$ total protein). When $\mathrm{NADH}$ was used as a cofactor, Tris/ $\mathrm{HCl}(\mathrm{pH} \mathrm{7.4)}$ was used. Enzyme activity was determined as the difference in oxidation rates of NADPH in the presence and absence of substrate. Enzyme specific activities are expressed as units (mg protein) ${ }^{-1}$ where one unit is defined as the amount of enzyme required to oxidize $1 \mu \mathrm{mol}$ cofactor $\mathrm{min}^{-1}$ at $25^{\circ} \mathrm{C}$. The protein concentrations of the CFEs were determined using the Bio-Rad dye reagent with bovine serum albumin as a standard.

GDH zymograms. CFEs ( $45 \mu$ g total protein) were subjected to discontinuous non-dissociating PAGE (Laemmli, 1970), modified by omitting SDS and $\beta$-mercaptoethanol, using the Mighty-Small system (Hoeffer Scientific Instruments). The acrylamide concentrations used were 7.5 and $3.5 \%$ in the stacking and resolving gels, respectively. Bromophenol blue was used as the tracking dye. Following electrophoresis, the gels were incubated in staining solution consisting of $0.5 \mathrm{mM}$ $\mathrm{NADP}^{+}$or $\mathrm{NAD}^{+}, 20 \mathrm{mM}$ L-glutamate, $0.3 \mathrm{mg}$ nitro blue tetrazolium $\mathrm{ml}^{-1}, 0.05 \mathrm{mg}$ phenazine methosulfate $\mathrm{ml}^{-1}$ and $50 \mathrm{mM}$ Tris $/ \mathrm{HCl}(\mathrm{pH} 8 \cdot 0)$. GDH activity appeared as dark purple bands against a clear background.

SDSPAGE analysis. Cell-free coupled transcription and translation (Amersham) were carried out on plasmid pGDH15 and pEcoR251 and the resultant $\left[{ }^{35} \mathrm{~S}\right]$ methionine-labelled polypeptides compared using $10 \%$ SDS-PAGE (Laemmli, 1970).

Southern blotting analysis. For Southern blotting analysis, restriction-endonuclease-digested $B$. fragilis $\mathrm{Bf} 1$ and $E$. coli JM109 DNA were transferred to a nylon membrane (Hybond$\mathrm{N}$; Amersham) via the capillary alkali transfer procedure. The $g d h B$ probe was generated by random-primed labelling of a $1.0 \mathrm{~kb} X m n \mathrm{I}-B g l \mathrm{II}$ fragment derived from pGDH15, using a non-radioactive digoxigenin labelling and detection kit (Boehringer Mannheim). Hybridization, washing and detection were performed according to manufacturers' instructions.

Northern blotting analysis. Total RNA was isolated from mid-exponential phase cultures $(30 \mathrm{ml})$ of $B$. fragilis $\mathrm{Bf} 1$ and $E$. coli MX3004(pGDH15), with E. coli MX3004(pMT104) being used as control (Aiba et al., 1981). Separation of RNA on formaldehyde gels, transfer to nylon membranes (Boehringer Mannheim) and hybridization conditions were according to manufacturers' instructions. Equal amounts of RNA $(15 \mu \mathrm{g})$ were loaded per lane and confirmed by the equal intensity of
rRNA bands by ethidium bromide staining. The $1.0 \mathrm{~kb}$ $X m n \mathrm{I}-B g l \mathrm{II}$ fragment used in Southern hybridization was used as probe. The RNA ladder from USB was used as size marker.

Nucleotide sequence and sequence analysis. Subclones for sequencing were constructed by the ExoIII nested deletion method of Henikoff (1984) using pBluescript $\mathrm{KS}(+)$ (Stratagene). The nucleotide sequence was determined by the fluorescent dideoxy chain-termination method of Sanger $e t$ al. (1977) using the Thermo-Sequenase Sequencing kit (USB) and Cy5 fluorescently labelled universal and reverse primers, as per manufacturers' instructions. The sequencing reaction products were separated using the ALFexpress DNA sequencer (Pharmacia) and the nucleotide sequence obtained was analysed using the University of Wisconsin Genetics Computer Group DNA sequence analysis software (Devereux et al., 1984) and CLUSTAL W, DNAMAN and TREEVIEW software packages.

\section{RESULTS}

\section{GDH activity of $B$. fragilis under various nitrogen conditions}

Initially, all experiments were conducted both aerobically and anaerobically, but since the enzyme activity was not found to be affected by oxygen, all subsequent assays were done aerobically. CFEs of $B$. fragilis grown in minimal or complete media showed both NADPH- and NADH-linked GDH activities. This represented the combined total activity of both the dual cofactor $\mathrm{NAD}(\mathrm{P}) \mathrm{H}$ - and the $\mathrm{NADH}$-specific $\mathrm{GDH}$ enzymes. The levels and ratios of the specific activity of each cofactor varied according to the levels of organic or inorganic nitrogen supplied (Table 1). When ammonia was the nitrogen source, the highest NADPH- and $\mathrm{NADH}$-linked specific activities were found at $0.5 \mathrm{mM}$ ammonia (1348 and $185 \mathrm{U}$ respectively) and the least at $50 \mathrm{mM}$ ammonia (291 and $80 \mathrm{U}$, respectively). When $B$. fragilis was grown in complete medium (supplemented BHI broth), NADH-linked activity exceeded that of $\mathrm{NADPH}$ (ratio NADH:NADPH $=1 \cdot 68$ ). Growth of $B$. fragilis with $0.25 \%$ tryptone resulted in an NADH: NADPH activity ratio of $0 \cdot 35$, compared with growth in $1.25 \%$ tryptone (ratio $=2.02$ ) (Table 1 ), reflecting the increased NADH- and reduced NADPHlinked GDH activity in the presence of high levels of organic nitrogen.

\section{Cloning and characterization of a GDH gene from B. fragilis}

Screening of a B. fragilis gene library in E. coli MX3004 grown on GMMN resulted in the isolation of plasmid pGDH15 which complemented the glutamate auxotrophy of the host cells. The recombinant plasmid was partially mapped using restriction endonuclease digestion (Fig. 1a) and found to contain a $5.7 \mathrm{~kb}$ DNA insert. The region conferring GDH activity was localized by deletion analysis of the cloned DNA, with a $1.9 \mathrm{~kb}$ BglII deletion, resulting in complete loss of the phenotype. Southern hybridization of the XmnI-BglII fragment of 
Table 1. GDH specific activity in $B$. fragilis $B f 1$ grown under different nitrogen conditions and in E. coli MX3004 transformed with the cloned gdhB gene

Values are the means of at least three different experiments \pm SD. One unit is defined as $\mu \mathrm{mol}$ cofactor oxidized $\min ^{-1}(\mathrm{mg} \text { protein })^{-1}$. ND, not detectable.

\begin{tabular}{|lccc|}
\hline $\begin{array}{l}\text { Organism and nitrogen } \\
\text { source }\end{array}$ & \multicolumn{3}{c|}{ Specific activity } \\
\cline { 2 - 4 } & NADPH-GDH (U) & NADH-GDH (U) & $\begin{array}{c}\text { Ratio } \\
\text { (NADH: NADPH) }\end{array}$ \\
\hline B. fragilis Bf1 & & & \\
$\mathrm{NH}_{4} \mathrm{Cl}(0 \cdot 5 \mathrm{mM})$ & $1348 \pm 69 \cdot 9$ & $185 \pm 4 \cdot 6$ & $0 \cdot 137$ \\
$\mathrm{NH}_{4} \mathrm{Cl}(5 \cdot 0 \mathrm{mM})$ & $784 \pm 22 \cdot 2$ & $120 \pm 6 \cdot 1$ & $0 \cdot 153$ \\
$\mathrm{NH}_{4} \mathrm{Cl}(50 \cdot 0 \mathrm{mM})$ & $291 \pm 18 \cdot 2$ & $80 \pm 5 \cdot 0$ & $0 \cdot 27$ \\
$\mathrm{BHI}$ & $107 \pm 7 \cdot 2$ & $180 \pm 16 \cdot 0$ & $1 \cdot 68$ \\
$\mathrm{Tryptone}(0 \cdot 25 \%)$ & $406 \pm 14 \cdot 7$ & $146 \pm 7 \cdot 2$ & $0 \cdot 35$ \\
$\mathrm{Tryptone}(1 \cdot 25 \%)$ & $85 \pm 9 \cdot 9$ & $172 \pm 12 \cdot 3$ & $2 \cdot 02$ \\
E. coli $\mathrm{MX3004}(\mathrm{pGDH})$ & & & \\
YT & $28 \pm 0 \cdot 0$ & $610 \pm 31 \cdot 2$ & $21 \cdot 78$ \\
YT + glucose $(0 \cdot 5 \%)$ & $20 \pm 0 \cdot 0$ & $366 \pm 17 \cdot 6$ & $18 \cdot 30$ \\
E. coli $\mathrm{MX3004}(\mathrm{pMT104})$ & $\mathrm{ND}$ & $\mathrm{ND}$ & - \\
\hline
\end{tabular}

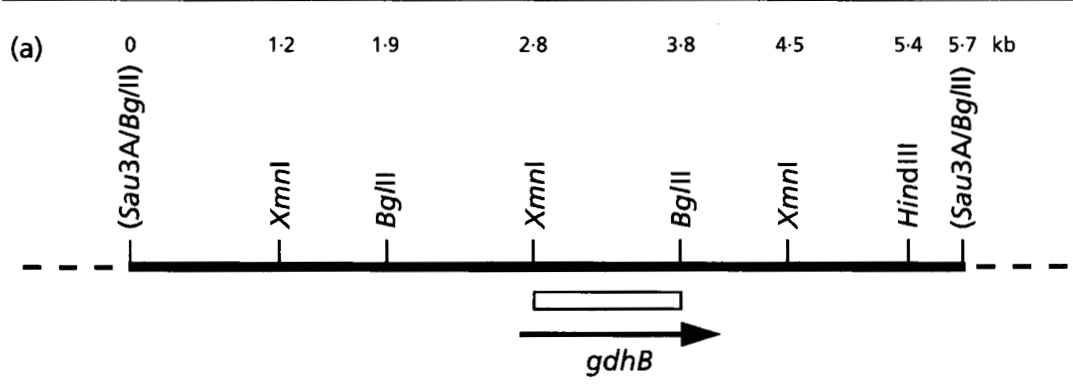

(b)

1 ACTATCCATATATGCACAGATTGCTTTCTCGTTTTCGGCTTAAAATCTCTCCTACTCTCATACGTATCGACCACAGGCCG

81 GACATGGTTCCAACAAAGCCACAACAAAGTTAGTAAAGGAGCAAGCAGACATCTATGCATTTATCTAGTATACCTGGGGA

161 TGAAATGAAATACTGACATAAATATCCGAATAGGTATTTTTGTCATTTTATCATTATTTAATCAAAATAATACGATTCCG

241 AATGACATCCAGAAAACTTTCTTATATTTGCCATATGAAACAAGTTACCATTTTATCAGAATCAACCTTTTTAAAACAT $-35$

321 ACTATTATC. ..........................

1681

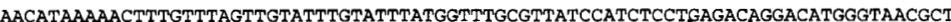

176

CTTTTTTATAAAAAGGTTTCATTTTCAACTAAAATCGCCTAACTTIGCATCTCGAAACCAAATAATAATACAAAATGTTA

(c)

$$
\begin{array}{r}
1 \\
26 \\
53 \\
80 \\
107 \\
134 \\
161 \\
188 \\
215 \\
242 \\
269 \\
296 \\
322 \\
350 \\
377 \\
404 \\
431
\end{array}
$$

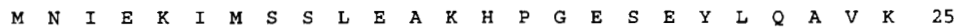

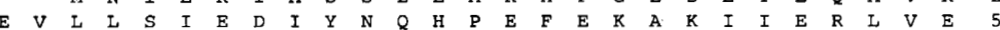

$\begin{array}{lllllllllllllllllllllllllllllllllllll}P & D & R & I & F & T & F & R & V & T & W & V & D & D & K & G & E & V & Q & T & N & L & G & Y & R & V & Q & 79\end{array}$

$\begin{array}{lllllllllllllllllllllllllllll}F & N & N & A & I & G & P & Y & K & G & G & I & R & F & H & \underline{\mathbf{L}} & \underline{\mathbf{S}} & \underline{\mathbf{V}} & \underline{\mathbf{N}} & \underline{\mathbf{L}} & \mathrm{S} & \mathrm{I} & \mathbf{L} & \underline{\mathbf{K}} & \underline{\mathbf{F}} & \underline{\mathbf{L}} & \underline{\mathbf{G}} & 106\end{array}$

\begin{tabular}{llllllllllllllllllllllllllll}
\hline & 0 & $T$ & $F$ & $X$ & $N$ & $A$ & $L$ & $T$ & $T$ & $L$ & $P$ & $M$ & $G$ & $G$ & $G$ & $K$ & $G$ & $G$ & $S$ & $D$ & $F$ & $S$ & $P$ & $R$ & $G$ & 133
\end{tabular}

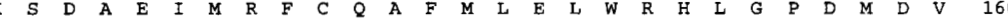

$\begin{array}{llllllllllllllllllllllllllllll}P & A & G & D & I & G & V & G & G & R & E & V & G & Y & M & F & G & M & Y & K & K & \text { L } & T & R & E & F & T & 1 B 7\end{array}$

$\begin{array}{lllllllllllllllllllllllllllll}G & T & F & T & G & K & G & \text { L } & \text { E } & F & G & G & \text { S } & \text { L } & \text { I } & \underline{R} & \underline{P} & \underline{E} & \mathbf{M} & \underline{T} & \underline{G} & \underline{F} & G & G & \text { L } & \text { Y } & \text { F } & 214\end{array}$

$\begin{array}{lllllllllllllllllllllllllllll}V & N & Q & M & L & Q & T & K & G & I & D & I & K & G & K & T & V & A & I & S & G & F & G & N & V & A & W & 24 I\end{array}$

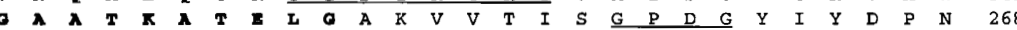

$\begin{array}{lllllllllllllllllllllllllllll}G & I & S & G & E & K & I & D & Y & M & \text { L } & E & \text { L } & R & A & S & G & \text { N } & \text { D } & \text { I } & \text { V } & \text { A } & \text { P } & Y & \text { A } & \text { D } & E & 295\end{array}$

$\begin{array}{llllllllllllllllllllllllllllll}F & P & G & S & T & F & V & A & G & K & R & P & W & E & V & K & A & D & I & A & L & P & C & A & T & Q & N & 322\end{array}$

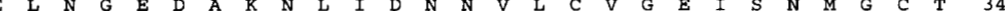

E A I D I F I E H

S G $\quad$ G

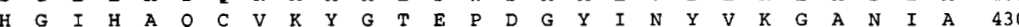

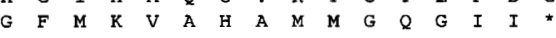

the insert to the equivalent band in B. fragilis DNA digested with the same enzymes and not to E. coli DNA confirmed that the insert DNA originated from $B$. fragilis (data not shown).
Fig. 1. (a) Partial restriction map of the $B$. fragilis $\mathrm{Bf1}$ DNA insert in pGDH15. The thick line represents the insert DNA and the dotted line the beginning of pEcoR251 vector DNA. The position and orientation of the $g d h B$ gene is shown by the arrow and the $X m n l-B g / l l$ fragment used as probe for Southern and Northern hybridization analysis is indicated by the open bar. The numbers mark the positions of the endonuclease restriction sites in the insert. (b) Partial nucleotide sequence of the $1.8 \mathrm{~kb}$ section of the pGDH15 insert DNA containing the $B$. fragilis $B f 1$ gdh $B$ gene. In the upstream region, the putative promoter regions are underlined. The ATG start codon and TGA stop codon are shown in bold, with the intervening coding region designated by dots. Arrows show the directions of the direct and indirect repeat sequences in the upstream and downstream regions. (c) The deduced amino acid sequence of gdhB showing the following features: conserved hexameric Family I GDH regions, bold and dashed underlined; GDH active site, bold underlined; NADPH binding site, bold; ATP/GTP binding site, underlined. 
(a)

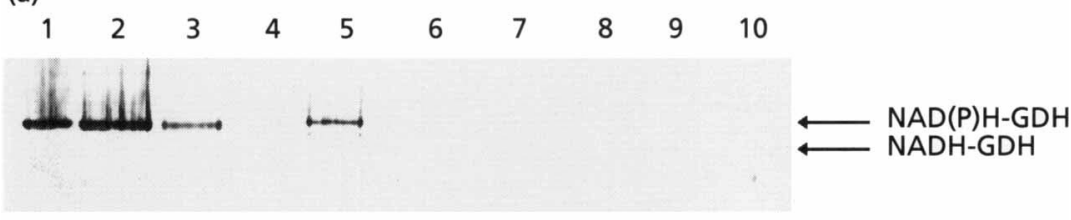

(b)

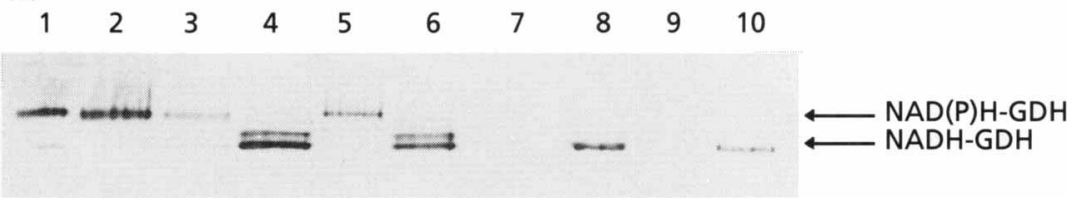

\begin{abstract}
Fig. 2. Activity staining of (a) NADPH- and (b) NADH-linked GDH activity on acrylamide gels. The extracts were prepared from $B$. fragilis cells grown under different nitrogen conditions and from E. coli MX3004 transformed with the cloned $g d h B$ gene or a control plasmid, with $45 \mu \mathrm{g}$ total protein run in each lane as described in Methods. B. fragilis cells were grown in $0.5 \mathrm{mM} \mathrm{NH}_{4} \mathrm{Cl}$ (lane 1), $5.0 \mathrm{mM} \mathrm{NH}_{4} \mathrm{Cl}$ (2), $50 \mathrm{mM} \mathrm{NH}_{4} \mathrm{Cl}$ (3), BHI (4), $0.25 \%$ tryptone (5) or $1.25 \%$ tryptone (6). E. coli MX3004(pGDH15) was grown in YT (lane 8 ) or $\mathrm{YT}+0.5 \%$ glucose (10). Lane 7, blank; lane 9, E. coli MX3004(pMT104) control.
\end{abstract}

compared to the GDH activity of the strain transformed with the control plasmid pMT104 (Table 1). During aerobic growth in YT broth, the cloned gene product was found to have NADH-specific GDH activity (610 U) while no activity could be detected in the control system. The cloned gene product had very low levels of NADPHlinked activity (28 U) (Table 1). An approximately twofold reduction in GDH activity was detected in $E$. coli MX3004(pGDH15) when it was grown anaerobically in YT supplemented with nitrate and glucose. The GDH repression effect was found to be caused by the addition of glucose, since the NADH-dependent activity of the recombinant enzyme was reduced to $366 \mathrm{U}$ when the cells were grown aerobically in YT supplemented with glucose.

\section{GDH zymograms}

The activities of the cloned GDH gene product in E. coli MX3004 and the resident GDH enzymes in B. fragilis were further characterized using non-denaturing PAGE and visualization by activity staining. Cell lysates from cells grown under all the conditions described above were investigated. Duplicate acrylamide gels were run with an equivalent amount of protein $(45 \mu \mathrm{g})$ loaded in each lane. After electrophoresis, the gels were stained for GDH activity, with either NADPH or NADH being added as the cofactor (Fig. 2a, b). The two B. fragilis GDH enzymes were clearly distinguishable, both in their electrophoretic mobilities and in their responses to the various cofactors and nitrogen sources supplied. Under low ammonia conditions $(0.5 \mathrm{mM})$, dual cofactor $\mathrm{NAD}(\mathrm{P}) \mathrm{H}$-dependent GDH was most active and only very low levels of the NADH-linked enzyme were detected. With increasing ammonia concentrations $(5$ and $50 \mathrm{mM}$ ), the $\mathrm{NAD}(\mathrm{P}) \mathrm{H}$-dependent $\mathrm{GDH}$ was progressively less active, but still easily detectable, while the $\mathrm{NADH}$-specific enzyme remained at very low basal levels. The NADH-specific activity detected in assays of the $B$. fragilis CFE at $0.5 \mathrm{mM} \mathrm{NH}_{4} \mathrm{Cl}$ was, therefore, being contributed predominantly by the dual cofactor enzyme. However, the situation was very different when organic nitrogen was present in the growth medium. During growth of $B$. fragilis in supplemented BHI broth, the NAD $(\mathrm{P}) \mathrm{H}$-dependent enzyme was not detected on the gels and high NADH-specific GDH activity was observed. Under conditions of low tryptone $(0.25 \%)$, the NAD $(\mathrm{P}) \mathrm{H}$-dependent enzyme was active, but not to the same extent as under low ammonia conditions. No NADH-linked activity was detected. However, when high levels of tryptone were present in the growth medium, the $\mathrm{NAD}(\mathrm{P}) \mathrm{H}$-linked $\mathrm{GDH}$ activity was no longer present and increased activity of the NADHdependent GDH was seen. The activity of the cloned GDH gene product in $E$. coli was confirmed to be $\mathrm{NADH}$-specific by the appearance of a single band of equivalent mobility to the enzyme in lysates of $B$. fragilis. No activity was detected in cells transformed with the control plasmid pMT104. Addition of glucose to the YT growth medium of E. coli MX3004(pGDH15) caused a reduction in NADH-dependent GDH activity.

\section{Nucleotide sequence analysis of the gdhB gene}

A $1640 \mathrm{bp}$ fragment containing the $g d h B$ gene was sequenced. Computer analysis of this region revealed an ORF of $1335 \mathrm{nt}$ from a presumptive start codon (ATG) at position 327 to a stop codon (TGA) at position 1664. A second in-frame ATG was found further upstream (position 276) that would yield a protein 17 aa larger. The most probable initiation codon, however, is the former, since the $\mathrm{N}$ terminus of the deduced polypeptide translated from ATG at position 327 shows homology with the $\mathrm{N}$ termini of the majority of GDHs sequenced so far. It generates a polypeptide of 445 aa with a deduced molecular mass of $49 \mathrm{kDa}$. This is in agreement with the results of SDS-PAGE analysis where a protein product of this size was encoded by the $g d h B$ gene (results not shown).

No conventional ribosome-binding site (Shine \& Dalgarno, 1974) was observed immediately upstream of the ORF, but further analysis of the upstream region showed the presence of putative promoter sequences (Fig. 1b) with homology to the -10 and -35 E. coli RNA polymerase binding consensus sequences. This may be recognized as a heterologous promoter in $E$. coli. It is not known whether this promoter is functional in $B$. fragilis. A perfect inverted repeat sequence was located in the promoter region. A $10 \mathrm{bp}$ direct repeat was identified upstream of the ORF and two inverted repeats 
were found downstream of the stop codon between positions 1721 and 1760, and 1761 and 1775 (Fig. 1b). At the RNA level, these inverted repeats would be capable of forming a stem-loop structure $[\Delta G=-21.4$ kcal mol $\left.{ }^{-1}\left(-89.5 \mathrm{~kJ} \mathrm{~mol}^{-1}\right)\right]$, similar to $\rho$-independent transcriptional terminators (Rosenberg \& Court, 1979).

The calculated $\mathrm{G}+\mathrm{C}$ content of the $g d h B$ gene was $46.5 \%$, which corresponds well with the range of $42-44 \%$ determined for chromosomal DNA from strains of $B$. fragilis (Holdeman \& Moore, 1972).

The deduced GdhB polypeptide possessed the three highly conserved domains characteristic of the Family I hexameric GDHs (Benachenhou-Lahfa et al., 1993). These are ASVNL (amino acid positions 95-99), KFLGFEQ (103-109) and RPEATGF (203-209). In addition, a putative NADP-binding motif, GFGNVAWGAATKATELG (binding site residues underlined), was located between residues 235 and 251 . The putative active site of the enzyme, GGGKGG (121-126), was also identified in which the critical lysine residue (124) in the glycine-rich region is thought to be involved in the binding of $\alpha$-ketoglutarate and the catalytic activity of the enzyme (reviewed by Smith $e t$ al., 1975). Three putative consensus GTP/ATP-binding motifs were evident, GIDIKGKT (223-230), GPDG (259-262) and VKAD (310-313), where both the sequence and spacing conformed to the required GTPbinding domains. No leader sequence was evident from the deduced polypeptide sequence, but the last 18 amino acids were strongly hydrophobic in character.

The deduced amino acid sequence of the $B$. fragilis $g d h B$ gene was aligned with the corresponding sequences of several other previously sequenced GDH enzymes. The highest identity was found with $B$. thetaiotaomicron gdhB (90\% ; Mark Morrison, personal communication). The identity to Porphyromonas gingivalis was $79 \%$ (Joe et al., 1994), followed by B. thetaiotaomicron gdhA (73\%; Baggio \& Morrison, 1996) and Prevotella ruminicola (66\%; Wen \& Morrison, 1996), all of which fall into Family I. Much lower identities were found with Family II enzymes, for example Clostridium difficile (37\% ; Lyerly et al., 1991) and Halobacterium salinarium (34\%; Benachenhou \& Baldacci, 1991).

\section{Northern hybridization analysis}

Analysis of the levels of mRNA produced from the $g d h B$ gene was carried out using total RNA obtained from $B$. fragilis grown under different nitrogen conditions and from E. coli transformed with the cloned gene (Fig. 3). The probe used was the $X m n \mathrm{I}-B g l \mathrm{II}$ internal fragment of the $g d h B$ gene and, in all cases, the amount of total RNA loaded in the lanes was the same $(15 \mu \mathrm{g})$. There was a correlation between the level of mRNA transcribed from the gdhB gene and the activity seen in the enzyme assays and on the GDH activity gels. The probe hybridized most strongly to the mRNA from $B$. fragilis cells grown in BHI broth and only very low basal levels of hybridization were seen with RNA from cells grown

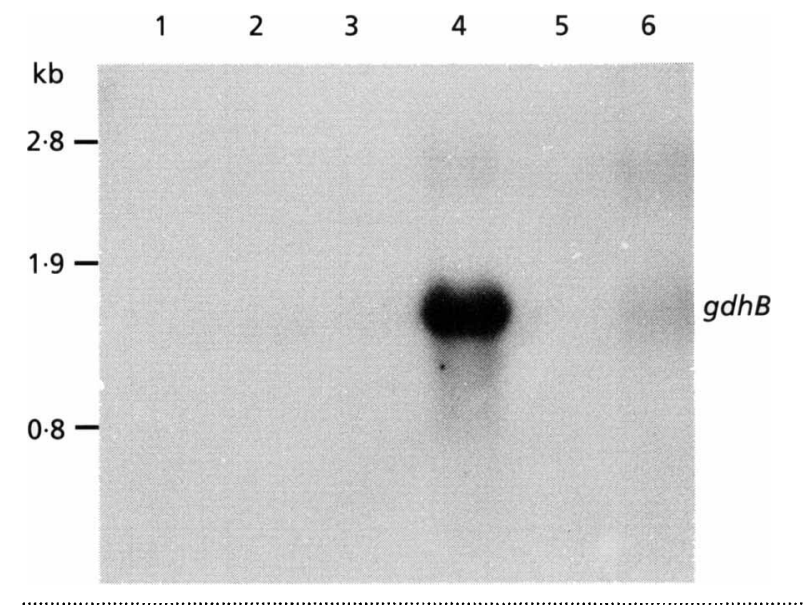

Fig. 3. Northern blotting analysis of RNA from $B$. fragilis $B f 1$ and $E$. coli $M \times 3004$ (pGDH15). Cells were grown to midexponential phase in various media as described in the text. The RNA was isolated and $15 \mu \mathrm{g}$ loaded into each well. The RNA was probed with the internal $X m n l-B g / l l$ fragment of the $g d h B$ gene. Lanes: 1, B. fragilis cells were grown in $0.5 \mathrm{mM} \mathrm{NH} \mathrm{m}_{4} \mathrm{Cl}$ (lane 1), $5.0 \mathrm{mM} \mathrm{NH}_{4} \mathrm{Cl}$ (2), $50 \mathrm{mM} \mathrm{NH}_{4} \mathrm{Cl}$ (3) or $\mathrm{BHI}$ (4). Lane 5 , E. coli MX3004(pMT104); lane 6, E. coli MX3004(pGDH15).

under all ammonia conditions. RNA isolated from $E$. coli transformed with the cloned gene hybridized to the probe and E. coli transformed with the control plasmid did not. Growth of $B$. fragilis in high peptides yielded higher levels of $g d h B$ mRNA than when cells were grown in low peptides (results not shown). These results demonstrate that there is transcriptional regulation of $\mathrm{GdhB}$ activity in response to the various nitrogen conditions.

\section{DISCUSSION}

The presence of two GDH enzymes in B. fragilis was first reported by Yamamoto et al. (1984) who proposed that the dual-cofactor-dependent enzyme was responsible for ammonia assimilation under conditions of low ammonia and that the NADH-specific GDH was induced when ammonia was in excess.

In this study, we have cloned the $g d h B$ gene for NADHspecific GDH and have characterized the recombinant GdhB enzyme with respect to its activity in the $B$. fragilis parent.

The $g d h B$ gene has many structural similarities to previously cloned GDH genes and was shown to be closely related to the hexameric GDH Family I group (Benachenhou-Lahfa et al., 1993). At a regulatory level, however, this enzyme appears to have an unusual role in the nitrogen metabolism of $B$. fragilis through its increased activity in the presence of organic nitrogen. The highest GdhB activity was observed when $B$. fragilis was grown in the presence of high levels of organic nitrogen, either in BHI broth or in minimal medium containing tryptone $(1 \cdot 25 \%)$ as sole nitrogen source. Under these conditions, the $\mathrm{NAD}(\mathrm{P}) \mathrm{H}$-linked activity of 
GdhA was repressed. The regulation of GdhB was shown to occur at the transcription level.

Yamamoto et al. (1984) noted a higher NADH to $\mathrm{NAD}(\mathrm{P}) \mathrm{H}$-dependent $\mathrm{GDH}$ activity ratio in high as compared to low ammonia. They regarded this as evidence for induction of the NADH-dependent GDH enzyme under high ammonia conditions. We have confirmed that the ratio does increase, but have seen no evidence of regulation of this enzyme by ammonia. Northern hybridization analysis showed that the same basal levels of $g d h B$ mRNA were produced under all ammonia conditions. Furthermore, the zymograms showed only faint bands of $\mathrm{NADH}$-specific GDH activity in all the ammonia-grown cultures. The difference in ratio may then be interpreted as a basal constitutive level of the GdhB enzyme being present throughout, with a repression of the dual cofactor GdhA enzyme with increased ammonia concentrations. A possible role for post-translational modification of the protein can not be ruled out at this stage. This is being investigated.

The regulation of $g d h B$ by peptides raises some interesting questions about the role of this enzyme in $B$. fragilis during in vivo growth. It has been shown in Clostridium botulinum (Hammer \& Johnson, 1988) that highly proteolytic strains have unusually high levels of NADH-dependent GDH activity relative to nonproteolytic strains. It is proposed that GDH is important in proteolytic strains of this organism to generate $\alpha$ ketoglutarate as a substrate for transamination reactions. $B$. fragilis has been shown to produce several proteases (Gibson \& Macfarlane, 1988a, b) and some protease enzymes from this organism have been cloned and characterized (Van Tassel et al., 1992; Chen et al., 1995; Kling et al., 1997; Franco et al., 1997). It has been suggested that proteases play a role in the pathogenesis of this organism (Riepe et al., 1980; Moncrief et al., 1995) and it has also been demonstrated that the levels of protease production vary with the availability of ammonia (MacFarlane et al., 1993), with less protease activity being evident under excess ammonia conditions. The regulation of $g d h B$ by organic nitrogen may be linked to protease activity and the breakdown of proteins in vivo, and hence to pathogenesis.

Sequence analysis of the cloned $g d h B$ gene indicated that optimal energy codons account for $38.2 \%$ of the $B$. fragilis $g d h B$ gene, indicating a significant physiological function for the GdhB enzyme. Most high expression systems possess between 15 and $25 \%$ optimum energy codons (Gharbia \& Shah, 1995). For example, the Clostridium symbiosum gdh gene contains one of the highest prokaryotic expression systems $(30.7 \%$ optimal codon usage) and the gene product accounts for $15 \%$ of total cellular protein, supporting the fact that optimal codon preference levels reflect the level of expression (Teller et al., 1992).

Sequence analysis of the $B$. fragilis $g d h B$ gene showed that it had a very high amino acid identity and similarity
(79 and $90 \%$, respectively) to the NADH-dependent GDH of Por. gingivalis, an anaerobic pathogenic organism occurring in the oral cavity. Por. gingivalis GDH has been shown to be surface-associated (Joe et al., 1993, 1994; Gharbia \& Shah, 1995), but it has been suggested that the enzyme may not be an integral membrane protein (Curtis et al., 1991) but may be loosely anchored in it through interaction of the 20 hydrophobic amino acid residues of the $\mathrm{C}$ terminus with the lipid bilayer of the membrane (Joe et al., 1994). The 18 -aa C terminus hydrophobic region found in $B$. fragilis is very similar to the structure of Por. gingivalis GDH. Work is currently in progress to raise antibodies to the recombinant GdhB protein and to do direct immunodetection studies on undisrupted $B$. fragilis cells.

The work reported here confirms that $B$. fragilis possesses two distinct GDH enzymes which are regulated by different nitrogen conditions. Further elucidation of the regulation of these enzymes will require cloning of the dual cofactor-dependent GDH gene. Sitedirected mutagenesis could then be used to establish the roles played by each enzyme in nitrogen assimilation in $B$. fragilis and perhaps in the virulence of this medically important pathogen.

\section{ACKNOWLEDGEMENTS}

The authors would like to thank Dr H. J. Goodman for her assistance in sequencing the $g d b B$ gene. The work was supported by a Research Grant from the Foundation for Research and Development.

\section{REFERENCES}

Abratt, V. R., Jones, D. T. \& Woods, D. R. (1985). Isolation and physiological characterisation of mitomycin C-sensitive/UVsensitive mutants in Bacteroides fragilis. J Gen Microbiol 131, 2479-2483.

Abratt, V. R., Zappe, H. \& Woods, D. R. (1993). A reporter gene vector to investigate the regulation of glutamine synthetase in Bacteroides fragilis Bf1. J Gen Microbiol 139, 59-65.

Aiba, H., Adhya, S. \& de Crombrugghe, B. (1981). Evidence for two functional gal promoters in intact Escherichia coli cells. J Biol Chem 256, 11905-11910.

Baggio, L. \& Morrison, M. (1996). The NAD(P)H-utilising glutamate dehydrogenase of Bacteroides thetaiotaomicron belongs to enzyme family I, and its activity is affected by transacting gene(s) positioned downstream of gdhA. J Bacteriol 178, 7212-7220.

Benachenhou, N. \& Baldacci, G. (1991). The gene for a halophilic glutamate dehydrogenase: sequence, transcriptional analysis and phylogenetic implications. Mol Gen Genet 230, 345-352.

Benachenhou-Lahfa, N., Forterre, P. \& Labedan, B. (1993). Evolution of glutamate dehydrogenase genes: evidence for two paralogous protein families and unusual branching patterns of the archaebacteria in the universal tree of life. $J$ Mol Evol 36, $335-346$.

Castano, I., Flores, N., Valle, F., Covarrubias, A. A. \& Bolivar, F. (1992). gltF, a member of the gltBDF operon of Escherichia coli, is involved in nitrogen-regulated gene expression. Mol Microbiol 6, 2733-2741. 
Chen, Y., Kinouchi, T., Kataoka, K., Akimoto, S. \& Ohnishi, Y. (1995). Purification and characterisation of a fibrinogen-degrading protease in Bacteroides fragilis strain $\mathrm{YCH} 46$. Microb Immunol 39, 967-977.

Curtis, M. A., Slaney, J. M., Carman, R. J. \& Johnson, N. W. (1991). Identification of the major surface protein antigens of Porphyromonas gingivalis using $\operatorname{IgG}$ antibody reactivity of periodontal case-control serum. Oral Microbiol Immunol 6, 321-326.

Devereux, J., Haeberli, P. \& Smithies, O. (1984). A comprehensive set of sequence analysis programs for the VAX. Nucleic Acids Res $12,387-395$.

Duncan, P. A., White, B. A. \& Mackie, R. I. (1992). Purification and properties of NADP-dependent glutamate dehydrogenase from Ruminococcus flavefaciens FD-1. Appl Environ Microbiol 58, 4032-4037.

Franco, A. A., Mundy, L. M., Trucksis, M., Wu, S., Kaper, J. B. \& Sears, C. L. (1997). Cloning and characterisation of the Bacteroides fragilis metalloprotease toxin gene. Infect Immun 65, 1007-1013.

Gharbia, S. E. \& Shah, H. N. (1995). Molecular analysis of surfaceassociated enzymes of Porphyromonas gingivalis. Clin Infect Dis 20, S160-166.

Gibson, S. A. \& Macfarlane, G. T. (1988a). Studies on the proteolytic activity of Bacteroides fragilis. J Gen Microbiol 134, 19-27.

Gibson, S. A. \& Macfarlane, G. T. (1988b). Characterization of proteases formed by Bacteroides fragilis. J Gen Microbiol 134, 2231-2240.

Hammer, B. A. \& Johnson, E. A. (1988). Purification, properties, and metabolic roles of $\mathrm{NAD}^{+}$-glutamate dehydrogenase in Clostridium botulinum 113B. Arch Microbiol 150, 460-464.

Henikoff, S. (1984). Unidirectional digestion with exonuclease III creates targeted breakpoints for DNA sequencing. Gene 28, 351-359.

Holdeman, L. V. \& Moore, W. E. C. (1972). Anaerobe Laboratory Manual, 4th edn. Blacksburg, VA: Virginia Polytechnic Institute and State University Anaerobe Laboratory.

Hill, R. T., Parker, J. R., Goodman, H. J., Jones, D. T. \& Woods, D. R. (1989). Molecular analysis of a novel glutamine synthetase of the anaerobe Bacteroides fragilis. J Gen Microbiol 135, 3271-3279 (corrigendum 136, 787).

Ish-Horowicz, D. \& Burke, J. F. (1981). Rapid and efficient cosmid cloning. Nucleic Acids Res 9, 2989-2998.

Joe, A., Yamamoto, A. \& McBride, B. C. (1993). Characterisation of recombinant and native forms of a cell surface antigen of Porphyromonas (Bacteroides) gingivalis. Infect Immun 61, 3294-3303.

Joe, A., Murray, C. S. \& McBride, B. C. (1994). Nucleotide sequence of a Porphyromonas gingivalis gene encoding a surface-associated glutamate dehydrogenase and construction of a glutamate dehydrogenase-deficient isogenic mutant. Infect Immun 62, 1358-1368.

Kling, J. J., Wright, R. L., Moncrief, J. S. \& Wilkins, T. D. (1997). Cloning and characterisation of the gene for the metalloprotease enterotoxin of Bacteroides fragilis. FEMS Microbiol Lett 146, 279-284.

Laemmli, U. K. (1970). Cleavage of structural proteins during the assembly of the head of bacteriophage T4. Nature 227, 680-685.

Lyerly, D., Barroso, L. A. \& Wilkins, T. D. (1991). Identification of the latex-reactive protein of Clostridium difficile as glutamate dehydrogenase. J Clin Microbiol 29, 2639-2642.

Macfarlane, G. T., Macfarlane, S. \& Gibson, S. A. W. (1993).
Synthesis and release of proteases by Bacteroides fragilis. Curr Microbiol 24, 55-59.

Moncrief, J. S., Obiso, R., Jr, Barroso, L. A., Kling, J. J., Wright, R. L., Van Tassell, R. L., Lyerly, D. M. \& Wilkins, T. D. (1995). The enterotoxin of Bacteroides fragilis is a metalloprotease. Infect Immun 63, 175-181.

Mossie, K. G., Jones, D. T., Robb, F. T. \& Woods, D. R. (1979). Characterisation and mode of action of a bacteriocin produced by a Bacteroides fragilis strain. Antimicrob Agents Chemother 16, 724-730.

Reitzer, L. J. \& Magasanik, B. (1987). Ammonia assimilation and the biosynthesis of glutamine, glutamate, aspartate, asparagine, L-alanine and D-alanine. In Escherichia coli and Salmonella typhimurium: Cellular and Molecular Biology, pp. 302-320. Edited by F. C. Neidhardt, J. L. Ingraham, K. Brooks Low, B. Magasanik, M. Schaechter \& H. E. Umbarger. Washington, DC: American Society for Microbiology.

Riepe, S.P., Goldstein, J. \& Alpens, D. H. (1980). Effects of secreted Bacteroides proteases on the human intestinal brush border enzymes. J Clin Invest 66, 314-322.

Rosenberg, M. \& Court, D. (1979). Regulatory sequences involved in the promotion and termination of RNA transcription. Annu Rev Genet 13, 319-353.

Saito, H., Yamamoto, I. \& Ishimoto, M. (1988). Reversible inactivation of glutamate dehydrogenase in Bacteroides fragilis: Purification and characterisation of high-activity and low-activity enzymes. J Gen Appl Microbiol 4, 377-385.

Sambrook, J., Fritsch, E. F. \& Maniatis, T. (1989). Molecular Cloning: a Laboratory Manual, 2nd edn. Cold Spring Harbor, NY: Cold Spring Harbor Laboratory.

Sanger, F., Nicklen, S. \& Coulson, A. R. (1977). DNA sequencing with chain-terminating inhibitors. Proc Natl Acad Sci USA 74, 5463-5467.

Shine, J. \& Dalgarno, L. (1974). The $3^{\prime}$-terminal sequence of Escherichia coli $16 \mathrm{~S}$ ribosomal RNA : complementarity to nonsense triplets and ribosome-binding sites. Proc Natl Acad Sci USA 71, 1342-1346.

Smith, E. L., Austen, B. M., Blumenthal, K. M. \& Nyc, J. F. (1975). Glutamate dehydrogenases. In The Enzymes, vol. II, pp. 293-367. Edited by P. D. Boyer. New York: Academic Press.

Southern, J. A., Parker, J. R. \& Woods, D. R. (1986). Expression and purification of glutamine synthetase cloned from Bacteroides fragilis. J Gen Microbiol 132, 2827-2835.

Southern, J. A., Parker, J. R. \& Woods, D. R. (1987). Novel structure, properties and inactivation of glutamine synthetase from cloned Bacteroides fragilis. J Gen Microbiol 133, 2437-2446.

Teller, J. K., Smith, R. J., McPherson, M. J., Engel, P. C. \& Guest, J. R. (1992). The glutamate dehydrogenase gene of Clostridium symbiosum: cloning by polymerase chain reaction, sequence analysis and over-expression in Escherichia coli. Eur J Biochem 206, 151-159.

Van Tassel, R. L., Lyerly, D. M. \& Wilkins, T. D. (1992). Purification and characterisation of an enterotoxin from Bacteroides fragilis. Infect Immun 60, 1343-1350.

Varel, V. H. \& Bryant, M.P. (1974). Nutritional features of Bacteroides fragilis subsp. fragilis. Appl Microbiol 28, 251-257.

Wehnert, G. U., Abratt, V. R., Goodman, H. J. K. \& Woods, D. R. (1990). Cloning of Bacteroides fragilis plasmid genes affecting metronidazole resistance and ultraviolet survival in Escherichia coli. Plasmid 23, 155-158.

Wen, Z. \& Morrison, M. (1996). The NAD $(\mathrm{P}) \mathrm{H}$-dependent glutamate dehydrogenase activities of Prevotella ruminicola $\mathrm{B}(1) 4$ 
can be attributed to one enzyme (GdhA), and $g d h A$ expression is regulated in response to the nitrogen source available for growth. Appl Environ Microbiol 62, 3826-3833.

Wen, Z. \& Morrison, M. (1997). Glutamate dehydrogenase activity profiles for type strains of ruminal Prevotella spp. Appl Environ Microbiol 63, 3314-3317.

Yamamoto, I., Abe, A., Saito, H. \& Ishimoto, M. (1984). The pathway of ammonia assimilation in Bacteroides fragilis. $J$ Gen Appl Microbiol 30, 499-508.

Yamamoto, I., Abe, A. \& Ishimoto, M. (1987a). Properties of glutamate dehydrogenase purified from Bacteroides fragilis. $J$ Biochem (Tokyo) 101, 1391-1397.

Yamamoto, I., Saito, H. \& Ishimoto, M. (1987b). Regulation of synthesis and reversible inactivation in vivo of dual coenzymespecific glutamate dehydrogenase in Bacteroides fragilis. J Gen Microbiol 133, 2773-2780.

Yanisch-Perron, C., Vieira, J. \& Messing, J. (1985). Improved M13 phage cloning vectors and host strains : nucleotide sequences of the M13mp18 and pUC19 vectors. Gene 33, 103-119.

Zabeau, M. \& Stanley, K. K. (1982). Enhanced expression of cro$\beta$-galactosidase fusion proteins under the control of the $\operatorname{Pr}$ promoter of bacteriophage lambda. EMBO J 1, 1217-1224.

Received 3 November 1997; revised 21 January 1998; accepted 11 February 1998. 